primarily to the public librarian, are of interest to those in charge of scientific or technical libraries and to those using such libraries for research or for other purposes. This applies particularly to the papers in the symposium on special materials in libraries, to which Dr. E. C. Willatts, of the Ministry of Town and Country Planning, contributes some notes on the cataloguing, classification and handling generally of maps, plans and aerial photographs, and Miss D. Tayler, formerly of the Ministry of Information, on the like treatment of pictorial material. Mrs. L. Moholy surveys the various processes of documentary reproduction, including the photostat process and micro-copying techniques, and urges once more the establishment of central offices of documentary reproduction; while two papers by Miss Marie T. Slocombe and Miss Valentine Britten, both of the British Broadcasting Corporation, dealing with sound recordings and describing the B.B.C.'s Recorded Programmes Library and the formation and administration of a gramophone library, respectively, should interest a more limited number of scientific workers. An excellent paper on "Library Co-operation and Publicity", by C. A. Elliott, of the Bermondsey Public Libraries, makes many sound points which could well be laid to heart by the works librarian or the librarian serving a research organisation in industry or elsewhere. The two-fold responsibility is the same: to provide an adequate service and to make it accessible. As in the public library, there is the task of organising an efficient service to meet known needs, of removing all unnecessary hindrances and barriers between the reader and the source of information, and of making known, continuously and effactively, the existence of the service so that it is fully used.

\section{Beilby Memorial Awards}

From the interest derived from the invested capital of the Sir George Beilby Memorial Fund, at intervals to be determined by the administrators, representing the Royal Institute of Chemistry, the Society of Chemical Industry, and the Institute of Metals, awards are made to British investigators in science to mark appreciation of records of distinguished work. Preference is given to investigations relating to the special interests of Sir George Beilby, including problems connected with fuel economy, chemical engineering and metallurgy, and awards are made, not on the result of any competition, but in recognition of continuous work of exceptional merit, bearing evidence of distinct advancement in science and practice. In general, awards are not applicable to workers of established repute, but are granted as an encouragement to younger men who have done original independent work of exceptional merit over a period of years. The administrators of the Fund will therefore be glad to have their attention directed to outstanding work of the nature indicated not later than November 1. All communications should be addressed to the Convenor, Sir George Beilby Memorial Fund, Royal Institute of Chemistry, 30 Russell Square, London, W.C.1.

\section{Information on Solar Activity by Radio}

As the central station for international co-operation on solar activity, the Swiss Federal Observatory at Zurich is now giving monthly the daily sunspot (relative) numbers by the short-wave service of the Swiss Broadcasting Corporation according to the following programme :

On the 4th of each month :

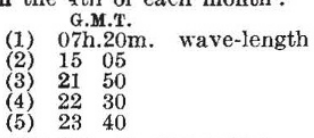

On the 5 th of each month :

(6) $01 \mathrm{~h} .40 \mathrm{~m}$. wave-length $31 \cdot 46 \quad 25 \cdot 28 \quad 19 \cdot 59$ for North America 31.4625 .2819 .59 , North America

For this year, in October, emission 2 will be on October 3 instead of October 4 . Emissions 3 and 5 are in Spanish, the others in English.

The Night Sky in September

New moon occurs on Sept. 14d. 19h. 28m., U.т., and full moon on Sept. 30d. 06h. 4lm. The following conjunctions with the moon take place: Sept. 10d. 11h., Mars $3^{\circ}$ N.; Sept. 12d. 10h., Saturn $4^{\circ}$ S. ; Sept. 19d. 10h., Jupiter $0 \cdot 6^{\circ}$ N. Mercury and Venus are badly placed for observation during the month and Venus is in superior conjunction on Sept. 3 . Mars, in the constellation of Gemini, is visible in the morning hours, rising a little before $0 \mathrm{~h}$. during the greater portion of the month. Jupiter, in the constellation of Libra, can be observed in the early part of the night, setting at $21 \mathrm{~h} ., 20 \mathrm{~h}$., and $19 \mathrm{~h} .20 \mathrm{~m}$. at the beginning, middle, and end of the month, respectively. Its stellar magnitude varies between -1.6 and -1.4 during September. Saturn can be seen in the constellation of Leo in the morning hours, rising at $3 \mathrm{~h}$. $05 \mathrm{~m} ., 2 \mathrm{~h} .20 \mathrm{~m}$., and $1 \mathrm{~h}$. $34 \mathrm{~m}$., at the beginning, middle, and end of the month, respectively, and is easily recognized by its yellowish hue. Only one occultation of stars brighter than magnitude 6 takes place: Sept. 28d. 01h. 42.5m., $\tau$ Aquar. $(D)$, the latitude of Greenwich being assumed and $D$ referring to disappearance. The autumnal equinox occurs on Sept. 23d. 21 h.

\section{Announcements}

The Committee of Privy Council for Medical Research has appointed Prof. N. Hamilton Fairley, professor of tropical medicine in the University of London, and Prof. J. H. Gaddum, professor of materia medica in the University of Edinburgh, to be members of the Medical Research Council as from October 1.

The Paint Research Association will celebrate its twenty-first anniversary on Tuesday, September 23 and following days, and the Paint Research Station, Teddington, will be open to visitors. On September 25 Sir Thomas Merton will give a short address, followed by a lecture by Dr. D. A. Sutton entitled "Is Copal Varnish an Alkyd?"; on the next day Sir. Lawrence Bragg will speak, and will be followed by a lecture by Dr. G. Herdan entitled "Paint and Mathematics". Applications to visit the Station should be sent to the Director, Paint Research Station, Waldegrave Road, Teddington, Middlesex.

THE twenty-second annual conference of the Association of Special Libraries and Information Bureaux will be held at the London School of Economics during September 20-21. The topics to be discussed include the effect of atomic energy developments on scientific and technical publication (Prof. R. E. Peierls); punched card systems in library work (Dr. J. W. Perry, Dr. W. E. Batten and Dr. G. M. Dyson); and format of periodicals (Dr. V. E. Parke, L. J. F. Brimble and L. G. Patrick). Particulars of the meeting can be obtained from the Secretary of the Association, 52 Bloomsbury Street, London, W.C.1. 